\title{
International Reserves and the Role of Special Drawing Rights
}

\author{
DOUGLAS R. MUDD
}

\section{T.}

HE increasing variability in the value of the U.S. dollar in foreign exchange markets has recently been the basis for discussion about the currency in which certain intemationally traded commodities are priced. In particular, petroleum exporting countries have given some consideration to the feasibility of denominating the world price of oil in terms of the Special Drawing Right (SDR), rather than the U.S. dollar. ${ }^{1}$ The primary function of the SDR, however, is not that of an international numeraire. Rather, the SDR was created in the late 1960 s to augment what was then generally perceived to be a deficiency of international reserves.

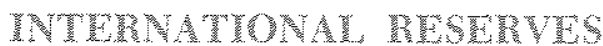

When the residents of a country import goods and services or invest in capital assets abroad, payment must be made in a manner acceptable to the exporters. Gold, currencies of other countries which the exporters are willing to accept, and the exporting country's domestic currency are international means of payment. The amounts of gold and internationally acceptable currencies (other than a country's domestic currency) which a nation has at its disposal for making final payment to foreign exporters are its international reserves. ${ }^{2}$

1"OPEC Might Switch to S.D.R.s If Dollar Plumments, Official Says," New York Times, Angust 4, 1977, "Kuwait Wants OPEC To Switch From Dollar To SDR-Based Pricing," Wall Street Joumal, August 4, 1977, and Gary R Gray, "SDRs and the Oil Price," New York Joumal of Commerce, December $10,197 \%$.

whe importance of gold as an intemational reserve asset has declined significantly since the early 1970s. During 1976 , offucial gold balances acconted for less than 20 percent of total international reserve assets. For a discussion see Hang Sheng Cheng and Nicholas $P$. Sargen, "The Changing Role of Gold in the Intenational Monelary System," Federal Reserve Bank of San Francisco Business Review (Winter $1974-75)$, pp. 5-15. The foreign currency component of international reserves also inches central barks holdurss of marketable securities denominated in foreign currencies.

\section{Under Fixed Exchange Rates}

Until the early $1970 \mathrm{~s}$, most countries had agreed upon the relative values of their currencies and acted in foreign exchange markets so as to attempt to preserve these relationships between currency values. ${ }^{3}$ Under this system of fixed relative values for national currencies, central banks bought and sold reserve assets at prices fixed in terms of their own domestic currencies. For example, suppose a particular country was maintaining the intemational value of one unit of its currency at one U.S. dollar. If importers in this country demanded dollars to pay for foreign goods and services, their own central bank would exchange dollars for domestic currency on a one-for-one basis. If this central bank's holdings of dollars were insufficient to satisfy the importers demand for dollars, it could obtain additional dollars by purchasing or borrowing them from another central bank. Direct purchases resulted in an exchange of gold or some internationally acceptable currency for U.S. dollars. In turn, the dollars were sold to domestic importers for domestic currency. The central bank's holdings of international reserves would thereby be reduced.

Thus, a deficit in a country's balance of payments (for example, due to a current account deficit not being offset by a capital account surplus) implied a decline in its central bank's holdings of international reserves, since balance-of-payments deficits were settled by flows of international reserves from deficit

\footnotetext{
"National currencies are bought and sold in foreign exchange makets. The price of one currency in terms of another is the exchange rate between the two conrencies. Throughout this paper it is assumed that exchange rates were fixed as single values. Currency values were in fact generally allowed to fluctiate within $-1 \%$ of a fixed single value. For a discus. sion of the par value exchange rate regime which existed until March 1973, see Helnut W. Mayer, "The Anatomy of Official Exchange-Rate Intervention Systems," Essays in Inter" national Finance, no. 104 (Princeton: Princeton University, May 1974).
} 
to surplus nations." The one exception to this was when the deficit nation's domestic currency was internationally acceptable. When the domestic currency of a particular nation was acceptable to foreign exporters, importers in that country could use their local currency to pay for foreign-made goods. In addition, the currency could also be used to purchase capital assets abroad. As a result, that country could pay for an increasing amount of inports by increasing its domestic money supply. In this case, however, importers conld continue to pay for foreign goods and securities with their domestic currency only so long as foreign exporters remained willing to accept that currency.

\section{Onder "Cleonly Flowhen" Fachonge Rates}

If a country allows its currency to "float cleanly", then the value of that cumency in terms of other currencies is established by the supply and demand conditions arising from all foreign exchange market transactions undertaken by the private sector (and those actions of govenments undertaken for purposes other than affecting exchange rates). When individnals or businesses require foreign currency to pay for foreign goods or capital assets, they can purchase that currency with their domestic currency in foreign exchange markets. An increased demand for the foreign currency results in a rise in the number of units of domestic currency required to purchase one unit of the foreign currency (the "price" of the foreign currency rises).

Such market-determined changes in the relative values of national currencies would automatically prevent the appearance of balance-of-payments deficits and sumpluses. This is because the exchange rate would adjust until the amount demanded for a currency equalled the amount supplied, with no central bank becoming a net absorber or supplier in foreign exchange markets. For example, as a country's cur rency dechnes in value relative to other currencies, the prices of foreign goods in terms of that nation's currency rise. Consequently, imports tend to decline. At the same time, prices of the country's goods in terms of foreign currencies fall, thus tending to increase exports." Hence, the nation's imports fall and

TThe balance of payments is defined here as the sim of all international transactions excluding those of monetary authorities. For an explanation of the current and capital accounts, see Donald S. Kenp, "Balance-of-Payments Comcepts - What Do they Really Mean?" this Reciew (July 1975), pp. 17-21.

For example, suppose the current value of one British pound is two U.S. dollars. Geods priced at two dollars in the U.S. would be priced at one pound in the United Kingdon (ignor- its exports rise, thereby reducing (and ultimately eliminating) the downward pressure on the currency.

Since balance-of-payments deficits and surpluses would not emerge under a "cleanly floating" exchange rate system, accumulation of international reserves to settle balance-of-payments deficits would be unnecessary and the level and growth of intemational reserves unimportant. However, exchange rates are seldom allowed to "float cleanly".

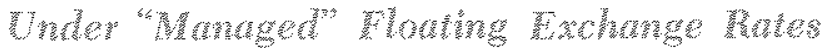

Since the early $1970 \mathrm{~s}$ an increasing number of countries have allowed the international values of their domestic currencies to be determined, to varying extent, by the supply and demand conditions prevailing in foreign exchange markets. Central banks, however, often intervene in foreign exchange markets to smooth day-to-day changes in the relative values of their currencies. 8 Govermment intervention occurs when a central bank either buys or sells its national currency in foreign exchange markets for the sole purpose of influencing its currency's relative

ing transport costs, tariffs, etc), If the U.K. imports moro from the U.S. Than it exponts to the U.S., the dollar value of the ponnd will dechne. This results from an thoreased demand for U.S. dollars in the foreign exchange market. As British inmorters increase their demand or U.S. dollars, the "price" of the dollar in temans of poands will rise-i.e., the namber of dollars which can be "purchased" for one pound will fall. Suppose the value of one pound declines to one dollar. The goods priced at wo dollars in the $U$. $S$. are now precel at two ponds in the U.K. Conversely, rooks priced at me pond in the U.K. would have been intially priced at two dollars in the U.S. Aster the decline in the pound's rela five value, the price of such goods in the U.S. wolld have cleclinet to one follar.

iAs the cownward pressure on the currency abates, investors becone mont willing to invest in that comotry. Thus, capital movements atso hep to stabilize the exchange rate

iFor example, see Raymond F. Mkesell and Henry N. Goldstein, "Rules for a Floating-Rate Regime," Essays in Inter" national Finance, no, 109 (Princeton: Princeton University, April 1975), p. 15. They also indicate that, even under a fleating rate system, rations might continue to mantain balances of reserve assets.

sBecanse of leads and lags in the adjustment of trade pattems (and possibly capital flows) to changes in exchange rates, an economy in disequilibrium would oscillate back toward an equibrim position. These oscillations, if not smoothed, would entail avoidable costs in terms of resource use. How ever, private sector specalation conll provide these smoothing effects as well as, and possibly better than, roremment intervention. See Milton Friedman, "The Case for Flexible Exchange Rates," in Exalfs in Positie Economics (Chicago: University of Chicago Press, 1953) pp. 157-203, and Ceoffrey $\mathrm{E}$. Wood, "The Witteven Facility," $I M F$ Supplem mentary Finaticing Facility, U.S. Congress, Senate Committee on Banking, Housing, and Urban Affairs, 95th Cong, 1st sess, October 13,1977 , pp. 76-79. 
value." To the extent that central banks intervene in foreign exchange markets, both the level and growth of international reserves remain important.

Prolonged one-way government intervention results in the relative values of various currencies being different from the values which would result if exchange rates were allowed to "Hoat cleanly". Since relative currency values are thereby prevented from fully adjusting to changes in international capital flows and in importers' demand for, and exporters' supply of, foreign currencies, balance-of-payments deficits and surpluses still persist. The persistence of a balance-of-payments deficit implies that the deficit country's central bank is purchasing its domestic currency with reserve assets (that is, foreign currencies) in foreign exchange markets. ${ }^{11}$ This course of action reduces the supply of a deficit country's currency in foreign exchange markets. The "price" of the currency in terms of other ctrrencies is thereby prevented from declining sufficiently to reduce the deficit. Such purchases can continue only so long as the deficit country's holdings of international reserves do not rum out (or so long as they can be supplemented by borrowing).

Thus, under the current "managed floating" exchange rate system, balance-of-payments deficits can be responded to by a combination of reserve flows and exchange rate changes. To the extent that a deficit country chooses to "support" its currency (that is, prevent its currency's relative value from declining sufficiently to fully correct the deficit), balance-ofpayments deficits are financed (but not corrected) by outflows of reserves.

\section{Thunathon hom whed to

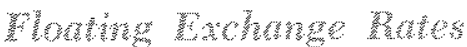

Under the system of fixed exchange rates, which existed prior to the early 1970 s, the values of many currencies were fixed in terms of either the U.S. dollar or the British pound sterling. ${ }^{11}$ The values of

\footnotetext{
"Such intervention wan be clifficult to identify. For example, if a national geverment purchases military equipment abroad or makes a payment under a foreign aid progran, supply and denand conditions in the foreign exchange market will change. These are not interventionist policy actions, unless they are timed to affect the exchange rate.

10The size of the current U.S. balance-of-trate deficit is due in pat to the purchase of U.S. clollars by foreign central banks. In effect, other central banks' intervention in foreign exchange narkets prevents the dollar's foreign excharge value from declining sufficiently to discourage U.S. imponts and encourage U.S exports.

11By August 13, 1971, only 5 of the 118 International Monetary Fund menber contries had notified the fend that
}

the dollar and sterling, in turn, were fixed in terms of gold. Since the U.S. and U.K. governments guaranteed other central banks that dollars and sterling could be converted into gold, central banks in general regarded their dollar and sterling balances as being "as good as gold". Thus, dollar and sterling balances were used to supplement gold as international reserves.

The supply of intemational reserves, for the most part, depended apon continuing U.S. balance-ofpayments deficits. The United States bought foreign goods and capital assets with dollars, which were then accumulated by foreign central banks. These dollar balances were subsequently used by various foreign central banks to finance their own balance of paynents deficits. The world supply of intemational reserves was thus largely dependent upon the domestic economic policies of the United States. Reductions in the U.S. deficit would ". . dry up the largest source of additions to reserves." 12

While other central banks were willing to accept dollars as reserve assets, foreign holdings of dollars could not expand sufficiently to satisfy foreign central banks' demand for reserves without a continuous U.S. balance-of-payments deficit. The United States could not continue ruming balance-of-payments deficits, however, without casting doubt upon the ability of the U.S. Government to maintain the fixed relative value of the dollar, ${ }^{13}$ This would ultimately reduce confidence in the dollar as an international reserve asset.

The elimination of the U.S. deficit and a corresponding reduction in the growth of international reserves during the last half of the 1960s led to increasing uncertainty as to how future increases in the demand for reserves could be satisfied. It was against this background that the International Monetary Fund (IMF) member countries decided to create an international reserve asset. ${ }^{14}$ The supply of, and con-

their currencies were "floating". The major "floating" currencies at that time were the Canadian dollar, Geman mark, and Dutch guilder.

12Margaret Garritsen de Vries, The Intemational Monetary Fund 1966-1971, vol. I (Washington, D.C.: Intemational Monetary Fud, 1976 ), p. 26.

${ }^{13}$ For an extended discussion of this analysis, see Robert Triffin Gold and the Dollar Grisis (New Haven: Yale University Press, 1960), and folm Willamson, "Intematiomal Liquidity: A Surey, Economic Joumal (September $1973)$, p1. 685-739, espectally po, $735-38$.

$11^{\text {Th The MF }}$ is an international institution among whose purposes are to "promote international monetary cooperation ... facilitate the expansion and balanced growth of intema tional trade. . shoten the duration and lessen the degree of disequalibrium in the intemational balances of payments 
fidence in, this new asset would be independent of any one country's domestic economic policies.

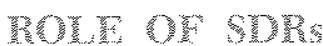

The new type of reserve asset which was created to help improve the functioning of the international payments system was the Special Drawing Right. which came into existence in 1969.15 SDRs were created as bookkeeping entries and were essentially given to all IMF member countries electing to receive them. These bookkeeping entries were designed to be transferred directly between central banks in settlement of balance-of-payments deficits, with the IMF guaranteeing their value in terms of a fixed amount of gold. Actual holders of SDRs have included only the central banks and Treasuries of IMF member countries which have agreed to accept them, and the IMF itself. Private institutions (such as commercial banks) and individuals (such as importers and exporters) cannot hold SDRs.

\section{SWR an a heserve Asset}

International transactions were being conducted within a system of generally fixed exchange rates at the time the SDR facility was established. The SDR was created to provide an alternative source for meeting increases in the demand for reserves. By allocating SDRs, the world supply of reserves could be augmented while the U.S. balance-of-payments deficit could be corrected. Elimination of the U.S. deficit would ensure confidence that the prevailing foreign currency value of the dollar could be maintained. The fixed exchange rate system could thus be preserved, with the SDR becoming the main reserve asset.

With changes in the supply of SDRs requiring the approval of 85 percent of nearly all IMF member countries' voting power, the supply of reserves could be placed under multinational control. ${ }^{11}$ Since the total supply of reserves would be largely independent of any one country's policy decisions, excessive in-

of members," See IMF Survey, Supplement on the Fund (Fall 1976), p. 1 .

${ }^{\mathrm{E}} \mathrm{A}$ A detailed account of the evolution of SDRs is presented by de Vries, Intemational Monetary Fund 1966-1971, pp. 11-250. Also see Martin Barrett, "Activation of the Special Drawing Fights Facility in the IMF," Federal Reserve Bank of New York Monthly Review (February 1970), pp. 40-46.

1 Only those menbers participating in the SDR scheme can vote on allocations and cancellations of SDRs. As of April 30,1977 , only eight of the $130 \mathrm{MF}^{\mathrm{M}}$ member conntries were not participating in the SDR facility. The 14 participating comtries classified as "industrialized" held about 60 percent of total votes, with the U.S. alone holding 21 percent. creases in reserves and the resultant inflationary pressures could, it was hoped, be avoided. ${ }^{17}$

The accomplishment of these objectives depended upon the SDR significantly reducing the importance of both gold and the U.S. dollar as reserve assets. If, on the other hand, central banks' holdings of SDRs did not comprise the butk of reserve assets, significant changes in total reserves could not be accomplished by changing the supply of SDRs.

The large U.S. balance-of-payments deficits in the early 1970 s, however, rendered the purposes for which SDRs were created irrelevant. The huge amounts of dollars accumulated by foreign central banks resulted in a significant reduction in confidence in the ability of the U.S. to maintain the fixed value of the dollar. As central banks' willingness to hold dollars as reserve assets declined, they attempted to purchase other currencies and gold with dollars. The resulting large increases in the supply of dollars in foreign exchange markets brought the entire structure of fixed exchange rates under increasing pressure and eventually became a major factor in the movement toward a system of relatively flexible exchange rates. ${ }^{18}$

\section{Quantuative Dfocts of SDRs \\ on Intemational Reserves}

Although the SDR has become generally accepted as an international reserve asset, the quantitative impact of SDRs upon total international reserves has been relatively minor. Following their initial alloca. tion in 1970, SDRs accounted for about 3 percent of total international reserves; following the second and third allocations in 1971 and 1972, SDRs accounted for about 5 percent and 6 percent, respectively, of total world reserves." Since no further allocations of

\footnotetext{
17 For a discussion of the inflationary impact of reserve growth during the early 1970 s, see David I. Fand, "World Reserves and World Inflation," Banca Nazionale del Lavoro Quarterly Rectew (December 1975), pp. 347-69.

18 For an analysis of the collapse of the fuxed exchange rate system, see John Williamson, The Failure of World Monetary Reform, 1971-74 (London: Thomas Nelson and Sons Ltd., 1977 ), pp. $1-52$

19SDRs were allocated to those IMF member comtries which elected to receive them, in proportion to the size of each country's quota. Upon beconing a member of the IMF, a country nunst agree zpon the size of its cuota. Twenty-five percent of the quota is deposited in the form of an international reserve asset (usually gold or U.S. dollars). The remaining 75 percent is deposited in the fom of the country's domestic currency. These quotas then fon a pool of MF nembers' currencies from which one nember can borrow another member's currency. The specific SDR allocan tions were: SDR 3.41 billion on Jamuary 1,1970 (each participant received 16.8 percent of its quota), SDR 2.95
} 
SDRs have been made since 1972, the total amount of SDRs in existence has remained at 9.31 billion. As total intemational reserves have risen contintiously since 1972, the proportion accounted for by SDRs has progressively declined, representing only about 4 percent of the total during 1976.

SDRs were allocated (with the intention of increasing the amount of international reserves) during a period in which total international reserves, particularly the foreigi currency component, were rising very rapidly. During the same three-year period in which SDRs were allocated (1970-72), the United States ran substantial balance-of-payments deficits. Foreign central banks accumulated large amomits of dollars, further increasing their holdings of international reserves. The foreign exchange component of intenational reserves (primarily dolars) more than dowbled over the $1970-72$ period, as total world reserves rose by more than 50 percent. Thus, foreign currency holdings have become the largest component of international reserve balances, and the SDR has never as sumed the role of main reserve asset that was envisaged for it.

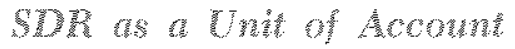

In recent years, the SDR has been increasingly used as an international unit of account. The SDR has been chosen, or is under consideration, as the reference value for establishing prices of certain internationally purchased services (air fares and canal tolls). Proposals for pricing internationally traded basic commodities, such as petroleum, in terms of SDRs have also been made as a result of the variability of the U.S. dollar's value in foreign exchange markets.

The "basket" method currently tred by the IMF to establish the value of the SDR is the reason for its use as a unit of account in transactions not involving the IMF. ${ }^{2}$ Since mid-1974, the daily valtue of the SDR has been computed as a weighted average of the U.S. dollar values of sixteen currencies. ${ }^{21}$

billion in 1971 ( 10.7 percent of quotas), and SDR 2.95 billon in 1972 ( 10.7 percent of quotas). The U.S. received a cumulative allocation of $\mathrm{SDR} 2,3$ billion, about 25 percent of the total allocated.

"OTransactions involving the IMF are denominated in SDRs.

21 prior to July 1,1974 , the value of the SDR had been fixed at 0.888671 gram of fine gold. Under the current method of valuing the SDR in terms of a "currency basket," the U.S. dollar, German matk, British pound sterling, and Japanese yen receive a combined weight of over 60 percent. For an example of the actual calculation of the U.S. dollar value of one SDR, see IMF Strveu, July 8, 1974, pp. 209, 213-14.
The value of the SDR in terms of any one currency has normally fluctuated less than the exchange rate between specific currencies. During the two years ending November 1977, for example, month-to-month changes in the dollar value of the SDR remained within a band of 2 percentage points. In contrast, the U.S. dollar values of the Canadian dollar, German mark, Japanese yen, and pound sterling fuctuated within bands of about 5.5 percent, 5 percent, 6 percent, and 8 percent, respectively. This relative stability of the value of the SDR, as compared to the dollar, makes it an attractive alternative to the dollar as a basis for pricing internationally traded goods and services during periods in which the relative value of the dollar is falling (or is volatile).

Pricing basic commodities in terms of SDRs, rather than in terms of the U.S. dollar, can be one way for countries exporting such commodities to reduce fluctuations in the over-all value of their export earnings. Denominating the prices of exported commodities (such as oil) in terms of SDRs rather than dollars would restrain the decline in the value of export revenues in terms of a currency other than the dollar when the dollar's value in foreign exchange markets is declining. (On the other hand, a link between the SDR's dollar value and the prices of exported commodities would also moderate a rise in the value of export revenues in terms of a currency other than the dollar during periods in which the dollar's foreign exchange value is rising.) However, since SDRs can" not be used as a means of payment between traders, conversion of a price denominated in SDRs into a currency equivalent price would be necessary before payment could be made.

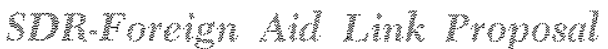

Proposals for linking foreign aid to SDR creation are designed to provide financial assistance to developing countries. ${ }^{2}$ The essence of such proposals is that the IMF allocate significant amounts of SDRs to developing countries. These countries could then use SDRs to finance balance-of-payments deficits arising from the large volume of imports (capital goods, for example) required by their various development programs. The effect of an SDR-development assistance link would ultimately be to transfer resources (that is,

\footnotetext{
2 For a recent discussion of the link proposal, see Committee on Reform of the International Monetary System and Related Essues, "Report of Technical Group on the SDR/Aid Link and Related Proposals," International Monetary Refom (Washington, D.C.: Intemational Monetary Fund, $1974)$, pp. 95-111.
} 
goods and services) from the industrial nations to the developing countries. It is therefore unlikely to be accepted so long as the industrial countries resist increasing direct resource transfers to the developing nations.

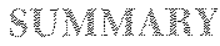

The trend toward a system of "managed floating" exchange rates has limited the SDR's importance as a reserve asset. The SDR was created under a system of generally fixed exchange rates and was designed to function under that system. Under the fixed exchange rate system, balance-of-payments deficits were settled by flows of reserve assets between central banks. As the system of floating exchange rates has evolved, the role of official international reserves in general has changed. The primary use of international reserves under a "managed Hoating" exchange rate system is in central banks' foreign exchange market intervention policies. Since SDRs cannot be held by commercial banks and traders (the major nongovernment foreign exchange market participants), central banks cannot directly use SDRs to influence exchange rates. Rather, SDRs must be converted, usually with IMF guidance, into an internationally acceptable currency before being used to affect exchange rate movements.

However, a proposed amendment to the IMF's Articles of Agreement is designed, in part, to strengthen the SDR as a reserve asset. Basically, the amendment would allow a wider range of holders of SDRs and more freedom in their use of SDRs. This could be a first step toward achieving the MMFs objective of ". . making the SDR the principal reserve asset in the international monetary system." 28

Because it is valued in terms of a "basket" of currencies, the SDR has gained some importance as a unit of account for international transactions. The value of privately arranged international bank deposits, loans, bond issues, and sales of goods and services can be linked to fluctuations in the SDR's relative value. The current use of the SDR as a unit of account in privately arranged international transactions is, however, quite limited. ${ }^{24}$

Although it has gained some attention as an international unit of account, the SDR's role in international transactions remains minor. So long as the world maintains a "managed floating" system of exchange rates, there should be no desire for international reserve growth on the scale the SDR was intended to provide.

29IMF Survey (Fall 1976), p. 8.

21For discussions of the SDR's limitations as an index for valuing international transactions, see C. Frederic Wiegold, "SDR in 2 Years Has Failed to Win Aceeptance As a Cushim Against Fxchange Fluctuations," American Banker, September 14, 1977, pp. 1, 22, and Crerald Kramer, "What are SDR's?" Columbia Journal of World Business (Fall 1976), pp. $53-59$

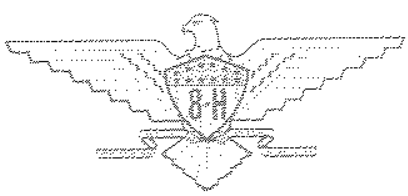

